\title{
無機固体電解質を用いた コイン型全固体リチウム二次電池の作動特性
}

\author{
岩本 和也*, 藤野信, 高田 和典, 近藤 繁雄
}

\section{Performance of Coin Type Solid State Battery with Inorganic Solid Electrolyte}

\author{
Kazuya IWAMOTO*, Makoto FUJINO, Kazunori TAKADA and Shigeo KONDO
}

Received December 24, 1996 ; Accepted June 12, 1997

\begin{abstract}
A lithium ion conductive glass, $\mathrm{Li}_{3} \mathrm{PO}_{4}-\mathrm{Li}_{2} \mathrm{~S}-\mathrm{SiS}_{2}$, has a high ionic conductivity of $10^{-3} \mathrm{~S} / \mathrm{cm}$ as well as a wide electrochemical potential window. Preliminary studies on electrochemical properties of $\mathrm{Li}_{1-x} \mathrm{CoO}_{2}$ and $\mathrm{In}-\mathrm{Li}_{2}$ in the glass revealed that the $\mathrm{In}-\mathrm{Li}_{\mathrm{x}} / \mathrm{Li}_{1-\mathrm{x}} \mathrm{CoO}_{2}$ battery has an excellent cycling property, a current drain as large as $1 \mathrm{~mA} / \mathrm{cm}^{2}$, and an extremely small residual current. Coin type cells with a construction of $\mathrm{In}-\mathrm{Li}_{\mathrm{x}} / \mathrm{Li}_{1 \cdot \mathrm{x}} \mathrm{CoO}_{2}$ were fabricated by using practical battery case, and the performances were compared with the coin - type rechargeable lithium batteries with organic electrolytes that have been already commercialized. The performances of the solid state batteries were not inferior to the commercialized ones.
\end{abstract}

\section{1 粕 言}

近年の移動体通信機器, 復带情報端末機器, パーソナ ルコンピュータなどのボータフル機器の進歩と普及に伴 い、これら機器の電源に用いられる電池の高性能化・高 信頼性化に対する要望が急速に高まってきている，とり わ嵪電圧・高エネルギー密度のリチウムイオン二次電 池の用途は機器の高性能化とともに急速に拡大している.

しかしながらこれらのリチウムイオンニ次電池には 電解筫として有機溶媒が使用されているため，漏夜・発 火等の可能性を皆無とすることができず，特に電池が大 型化するに伴い、その信頼性に関する課題がクロースア ッブされてきた"．この可燃性の電解液を不燃性の固体 電解筫に代えることにより，このような課題を解決し， 電池の信頼性を高めうることから，電池の全固体化への 試みが各方面でなされている ${ }^{2-6)}$.

全固体電池に用いられる固体電解質は理想的には，電 子伝導性を持たず，またりチウムイオンのみが移動する イオン選杓性を有するものである. 理想的な固体電解筫

昖下電池工業（株）技術研究所（宁570 守口市松下町 1 番 1 号)

Technology Laboratory, Matsushita Battery Industrial Co., LTD. (1-1, Matushita-cho, Moriguchi-shi, Osaka, 570)

Key Words: Solid State Secondary Battery, Lithium Ion Conductive Glass
を用いて電池を構成した場合，電解頃の分解などの副反 応が生しにくいため, 充放電效率が $100 \%$ となるととも に，自己放電が少なく，充放電サイクル特性に優れた電 池となる ${ }^{4}$.しいしながら、これまでに報告されてきた 固体電解筫 ${ }^{2-4)}$ の多くはイオン伝導性が低く，この低い伝 導度を補い，電池の内部インピーダンスを下げるため全 固体電池の研究は蒸着あるいはスパッタ等の手法を用い た薄膜系が主体となっていた.しかしながら、こうした 薄膜電池は大面糟化・高容量化が困難であり，また製造 コストも高くなることから実用化に到っていないのが現 状である。

我々はこれまでに号いイオン電導度(バルク：1.8× $10^{-3} \mathrm{~S} / \mathrm{cm}$, 粉末成型体 : $5 \times 10^{-4} \mathrm{~S} / \mathrm{cm}$ (いずれも室温)を示 す超急冷ガラス $\left(\mathrm{Li}_{3} \mathrm{PO}_{4}-\mathrm{Li}_{2} \mathrm{~S}-\mathrm{SiS} \mathrm{S}_{2}\right)$ を固体電解筫 $\left.7-10\right)$ として用い，正極活物筫としてコバルト酸リチゥム $(\mathrm{LiCoO} 2) ，$ 真極活物筫として金属インジウム $(\mathrm{In})$ 䇴 を用い，粉末成型法によるモデルセルを構成し，その特 性を報告してきた"1.12)．

本報では，同構成のR2016 サイスのコイン型の全固体 リチウム二次電池を作製し，その特性について調べた結 果を報告する。

\section{2 実 臨}

2. 1 コイン型全固体電池の作製

本電池に用いた固体電解筫である硫化物ガラスは 
$\mathrm{Li}_{3} \mathrm{PO}_{4}, \mathrm{Li}_{2} \mathrm{~S}, \mathrm{SiS}_{2}$ をモル比で 1:63:36 に湦合したもの をグラッシーカーボン製るつほに入れ，䡎燥窑素基国気 中で $1000^{\circ} \mathrm{C} て ゙ ~ 2$ 時間加熱溶融し，その融液を双ローラー 法により超急冷し，作蔽した，得られた固体解触ガラ スを粉碎し，固体䨘解算粉末とした。

また，正極はコバルト酸リチウム $\left(\mathrm{LiCOO}_{2}\right)$ と矛め粉

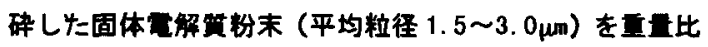
で 6:4 となるように, ボールミルで 1 時間混合し, 正梗 合靔とした.

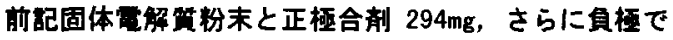
あるインジウム $100 \mathrm{mg}$ をプレス機を用いて，三思一体に 成形し，このペレットをR2016サイス（直径 $20 \mathrm{~mm}$ ，厈さ 1. $6 \mathrm{~mm})$ のコイン型軍池ヶースに捅入して封口し，Fig.1 に示すコイン型全固体リチウム二次雷池を作䌘した.

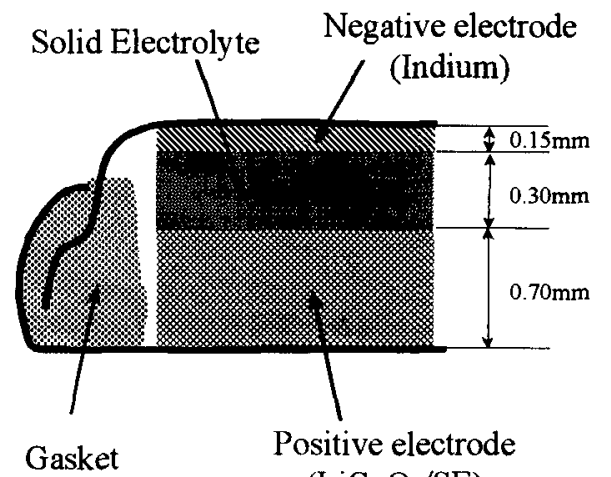

$\left(\mathrm{LiCoO}_{2} / \mathrm{SE}\right)$

Fig.1 Cross sectional view of the coin-type solid state battery.

\section{2 池特性の翀定 \\ 2. 2.1 充放露特性}

コイン型全固体リチウム二次而池の充放軍特性は察围

気温度 $20^{\circ} \mathrm{C}$ 下, 定西流法により调べた.

充雷及び放要の電流值はそれぞれ 250,500, $1000 \mu \mathrm{A}$,

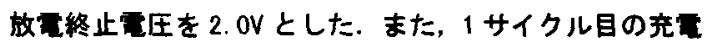
は正極活物英について式（1）に示す反応に相当する 21. $7 \mathrm{mAh}$ の定電気量充雷を行い,

$$
\mathrm{LiCoO}_{2} \rightarrow \mathrm{Li}_{0.55} \mathrm{CoO}_{2}+0.45 \mathrm{Li}^{+}+0.45 e^{-}
$$

2サイクル目以降は1サイクル目の充要到達征圧を終了 雷圧とした電圧カットの定流充雷とした.

\section{2.2 放等負荷特性}

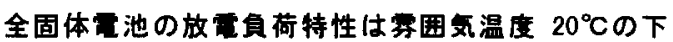
$500 \mu \mathrm{A}$ で充要し，穿围気温度 $-20,0,20,60^{\circ} \mathrm{C}$ 恒温指 中で $25 \sim 4000 \mu A$ の穊国の定電流で放金し，洞定した.

\section{2.3 保存試确}

全固体電池の保存特性は充定状態と放要状態の雷池を

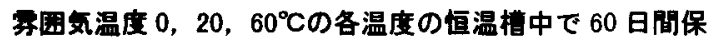

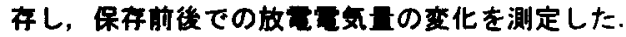

充正状態で保存した池については保存後，空温に民

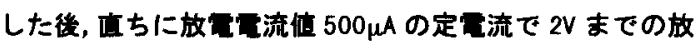
金特性を調べた.

一方，放正状態で保存した雷池は室温に层した後，

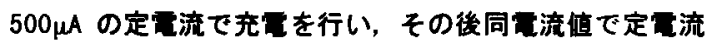
放而虹䮲を行った。

また，保存期間中 1 调間こととに桓温槽から雷池を取り 出し, 室温での開回路雷圧およびインピーダンスの测定 を行った。

\section{2.4 遏充而战路}

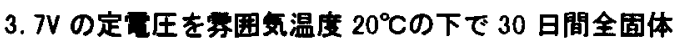

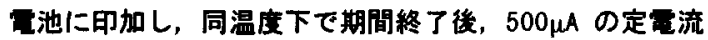

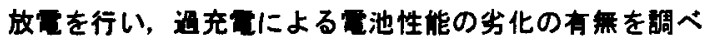
た.

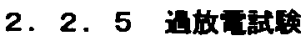

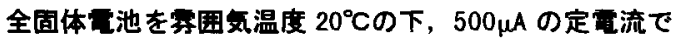
OV まで放寅した後，池の正負極を同温度下で 30 日間 短絡させた．期間終了後同温度下で $500 \mu$ A の定電流で 池を一旦充てした後，同军流值で放雷し，過放雷による 霍池の放電性能の劣化の有薙を睭べた。

\section{3 结果}

\section{1 充放证恃性}

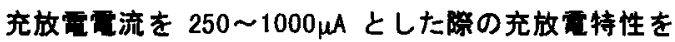
Fig. 2に示す.

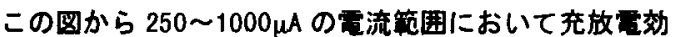
率はほほ 100\%で動作し，その放電電気量は充放電䆛流

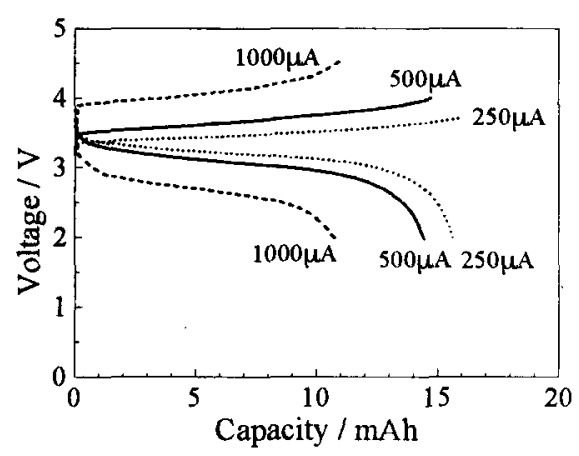

Fig.2 Charge-discharge curves of the 2016size coin-type solid state battery. 


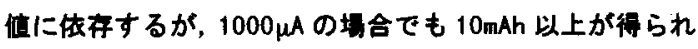
ることが明らかとなった.

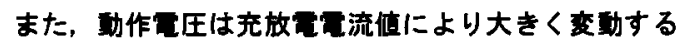

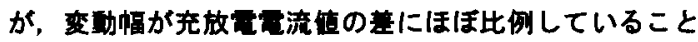
から，オーミックな成分による冒流分極であると考えら

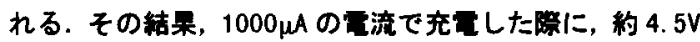

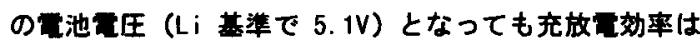

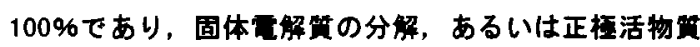
$\mathrm{LiCoO}{ }_{2}$ の結晶棤造破填が生しることはないものと推察さ

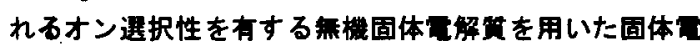
池は元来，充放軍時における副反応が生しににい，その

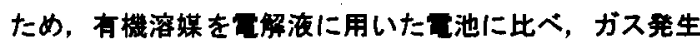

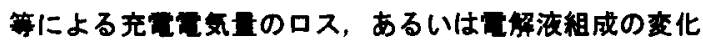
によるサイクル特性劣化は梗めて小さく， S.D. Jones ら

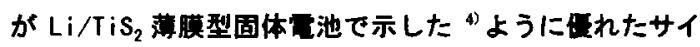

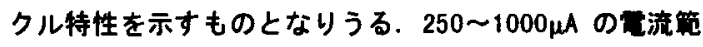

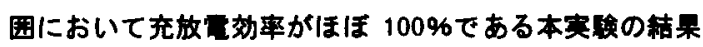
は， $\mathrm{Li}_{3} \mathrm{PO}_{4}-\mathrm{Li}_{2} \mathrm{~S}-\mathrm{SiS}$ 固体雷解籊が副反応を生じず，本固 体浣池もまた長サイクル来命をもつ可能性を示すものと 考えられる.

\section{2 放電負荷特性}

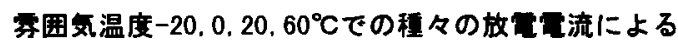
放西曲線をFig.3に示す。

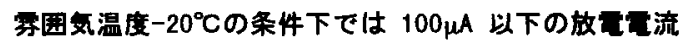

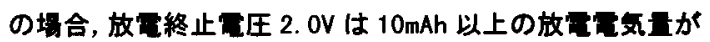

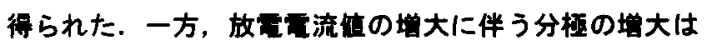

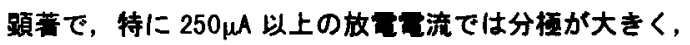
作動電压の平坦性に乏しいことがわかった. それに対し て，雾囲気温度 $60^{\circ} \mathrm{C}$ で $3000 \mu \mathrm{A}$ までは放而終止而压 $2.0 \mathrm{~V}$ で $10 \mathrm{mAh}$ 以上の放雷雪気が得られ，放而流值の大小

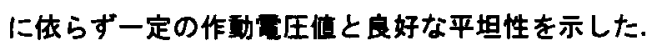

また, 放電霞気量は放電西流值が小さくなるほど增大

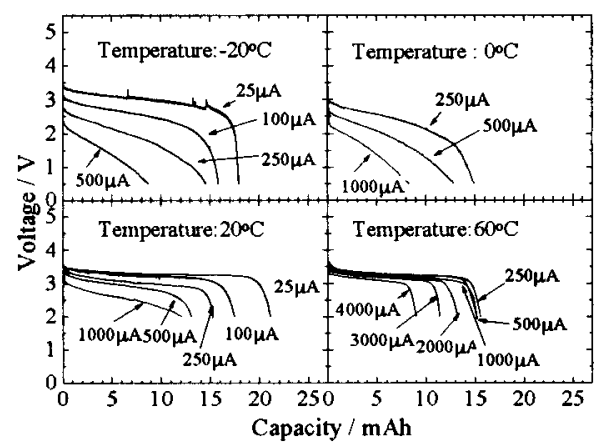

Fig.3 Discharge curves at various temperature.

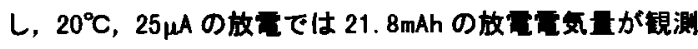

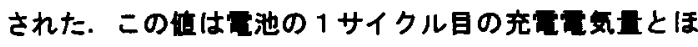
ほ第しい值であった. このことより，この電池の理磁的 な容量に比へ，实際の放而视量が低い原因は，充而時 に副反応が生じるためではなく，高率放時には放要末 期の分桓が增大することによるものと考えられる。

\section{3 保存特性}

充而状態の而池の保存特性を Fig. 4 に示す. 閒回路更 圧及びインピータンスは保存期間中变勒は现められず， また保存温度による堁寒もほとんど琶められなかった。

また，保存後の放四特性も保存前と比べ，ほとんど基 荤は思められなかった.
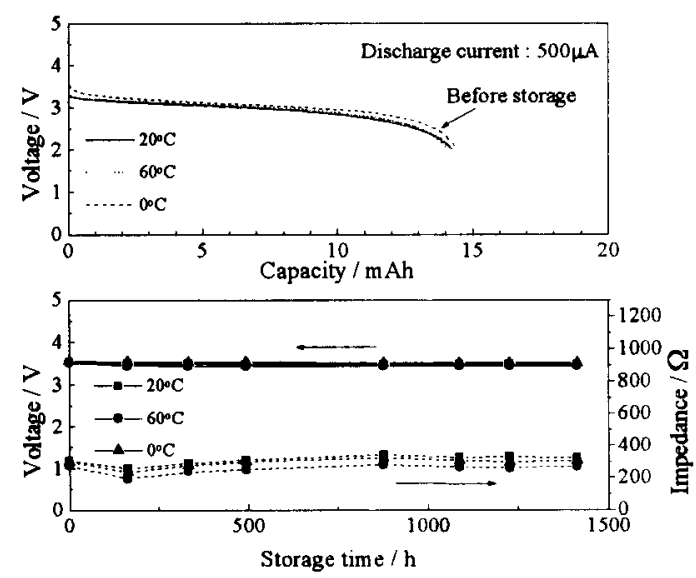

Fig.4 Storage characteristics of charged cells.
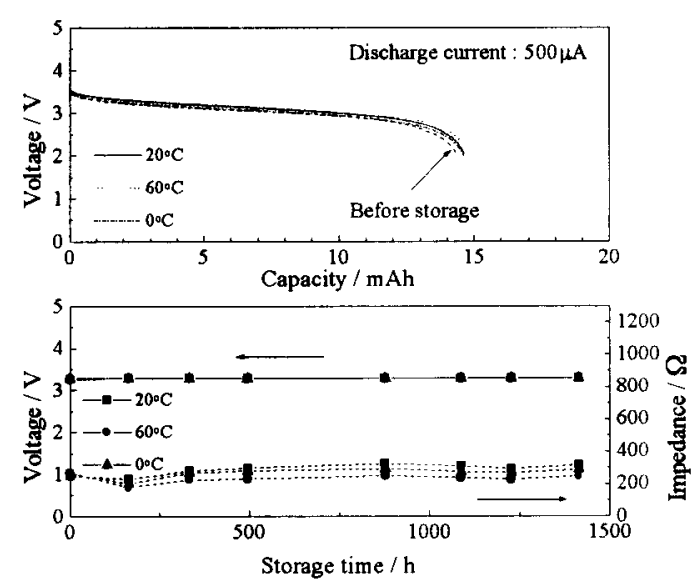

Fig.5 Storage characteristics of discharged cells. 


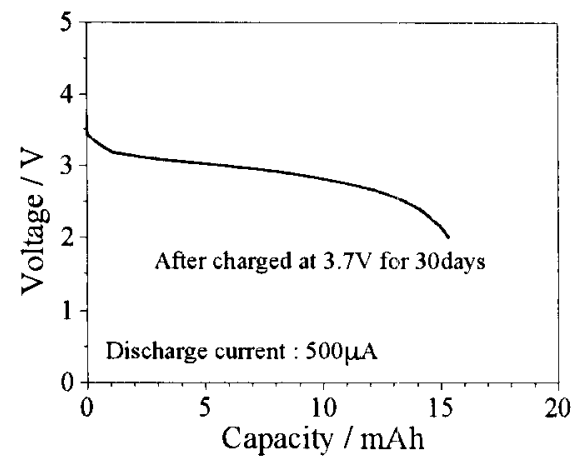

Fig.6 Discharge curve after charged at 3.7V for 30days.

放電状態の電池の保存特性をFig.5 に示す，電池を放 電後保存した場合にも, 開回路電死及びインピーダンス は保存期間中ほぼ定であった。また再充電後, 放電し た結果，放電電気量も保存前後では差違は認められず，

良好な放電保存特性を示した。

これらのことから $0 \sim 60^{\circ} \mathrm{C}$ 温庭域では，充電状態， 放電状態に関わらず，良好な保存特性を示し，自己放電 がほとんど起こらない電池であることがわかった.また, 固体電解貿と正極活物質あるいは偩極活物筫の界面で高 インピーダンス層が形成されることもなく，安定な界面 を保ち続けているものと推察された。

\section{4 调充電特性}

$20^{\circ} \mathrm{C}$ の霝囲気で定電圧 3.7V を30 日間印加した後, $500 \mu \mathrm{A}$ の定電流放電を行った結果装Fig. 6 に示す.

過充電の前後で放電挙動にほとんど差違は视められず， 放電電気量は $15 \mathrm{mAh}$ であった.これは $\mathrm{Li}_{3} \mathrm{PO}_{4}-\mathrm{Li}_{2} \mathrm{~S}-\mathrm{SiS}$ 固体電解質ガラスが電気化学的酸化に対して極めて安定

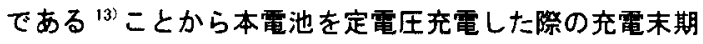
において，電解筫の分解などの副反心による電流がほと んど流れなくなり13，過充電に対して高い耐性を示した ものと考えられる.

\section{5 道放電特性}

$20^{\circ} \mathrm{C}$ の雲囲気で電池を 30 日間短絡させた後, $500 \mu \mathrm{A} の$

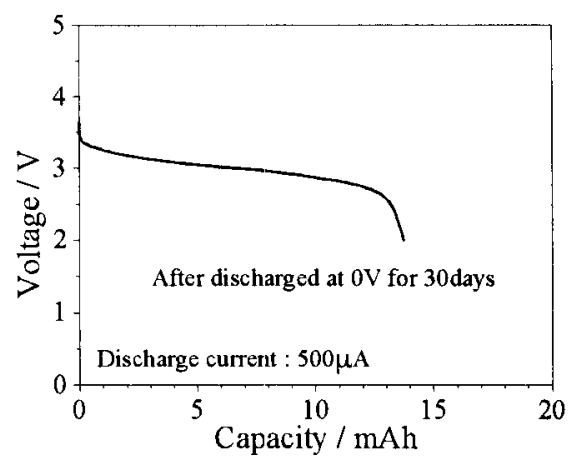

Fig. 7 Discharge curve after discharged at $0 \mathrm{~V}$ for 30days.

定電流で再充電後，同電流により放電を行った結果を Fig.7に示す.

過放電の前後で放電電気量にほとんど差違は認められ ず，約 $15 \mathrm{mAh}$ となり，本電池系は過放電あるいは電池の 外部短絡が起こっても容量回復性に優れていることがわ かった.

\section{4 まとめ}

$\mathrm{Li}_{3} \mathrm{PO}_{4}-\mathrm{Li}_{2} \mathrm{~S}-\mathrm{SiS}_{2}$ 固体電解筫ガラスを用いた $\mathrm{ln} / \mathrm{Li}-$ $\mathrm{CoO}_{2}$ コイン型全固体リチウム二次電池の特性について以 下のことが明らかとなった。

$\mathrm{Li}_{3} \mathrm{PO}_{4}-\mathrm{Li}_{2} \mathrm{~S}-\mathrm{SiS}_{2}$ 固体電解筫ガラスを用いたコイン型 全固体リチウム二次電池は，従来の電解液を用いたリチ ウム二次電池とは異なり，充電時において電解液の分解 反応が起こらないため

\section{(1) 是れた充放電特性}

(2) 高い耐過充電特性

を有することがわかった。

また，従来のリチウム電池では電池を過放電させた場 合, あるいは電池を高温保存すると, 電池容量が低下し たり，保存中に自己放電が生じるといった現象が認めら れる.しかし、ここで用いた無機固体電解筫はイオン選 択性を有し，電子伝導性を持たないため，自己放電が小 さく,

Table 1 Specifications for the solid state battery.

\begin{tabular}{l||ccccc}
\hline \multicolumn{1}{c||}{ Model name } & $\begin{array}{c}\text { Nominal } \\
\text { voltage } \\
(\mathrm{V})\end{array}$ & $\begin{array}{c}\text { Nominal } \\
\text { capacity } \\
(\mathrm{mAh})\end{array}$ & $\begin{array}{c}\text { Recommended } \\
\text { discharge current }\end{array}$ & \multicolumn{2}{c}{ Energy density } \\
$(\mu \mathrm{A})$ & $(\mathrm{mWh} / \mathrm{g})$ & $\left(\mathrm{mWh} / \mathrm{cm}^{3}\right)$ \\
\hline VL2020 (Li-alloy/ $\left.\mathrm{V}_{2} \mathrm{O}_{5}\right)$ & 3.0 & 20 & $1-70$ & 27.3 & 95.5 \\
CL2020 (Li-alloy / Carbon) & 3.0 & 1 & $1-100$ & 1.4 & 4.8 \\
Solid State Battery (2016 size) & 3.5 & 16 & 250 & 32.9 & 111.4 \\
\hline
\end{tabular}




\section{(3) 高い耐通放電特性}

(4) 慢れた保存特性

を有することがわかった。

また，現在市販されている類似サイスのコイン型リチ ウム二次電池（当社カタログ値）と比較を行っだ結果を Table 1に示す.

この表から本固体電池は公称電圧，放電電流值，エネ ルギ一密度の点で,これらの電池系と比較しても，同等 かあるいはそれ以上の特性を有していることが明らかと なった.

しかしながら，本固体電池に用いた無機固体電解筫は 加工性に乏しい，すなわち，ガラスバルク，粉体成型品 とも非常に堅く，脆いため，大面積化が困難であるとい う課題を有する．しかし，固体電解筫とポリマーとの複 合によってシート状電解管 ${ }^{14.193}$ を開発することにより， 固体電解筫の大面稙化を可能とならしめ，その結果将来 において全く新しい信頼性”安全性の極めて高い大型全 固体リチウム電池の出現に寄与すると考えられる.

\section{文献}

I) D. H. Doughty and S. C. Levy, Extend abstracts of the 36th Battery Symp. Jpn., 1, Kyoto (1995).

2) K. Kanehori, K. Matsumoto, K. Miyauchi, and T. Kudo, Solid State lonics, 9\&10, 1445 (1983).

3) H. Ohtsuka, S. Okada, and J. Yamaki, Solid State Ionics, 40/41, 964 (1990).
4) S. D. Jones and J. R. Akridge, Solid State Ionics, 53-56, 628 (1992).

5) JP. Malugani, B. Fahys, R. Mercier and G. Robert, Solid State Ionics, 9\&10, 659 (1983).

6) J. R. Akridge and H. Vourlis, Solid State Ionics, 28-30, 841 (1988).

7) N. Aotani, K. Iwamoto, K. Takada and S. Kondo, Solid State Ionics, 68, 35 (1994).

8) S. Kondo, K. Takada and Y. Yamamura, Solid State Ionics, 53-56, 1183 (1992).

9) K. Takada, N. Aotani and S. Kondo, J. Power Sources, 43-44, 135 (1993).

10) M. Tatsumisago, K. Hirai, T.Minami, K. Takada and S. Kondo, J. Ceram. Soc. Jpn., 101, 1315 (1993).

11) K. Iwamoto, N. Aotani, K. Takada and S. Kondo, Solid State Ionics, 79, 288 (1995).

12) K. Takada, N. Aotani, K. Iwamoto, S. Kondo, Solid State Ionics, 79, 284 (1995).

13) K. Takada, N. Aotani, K. Iwamoto and S. Kondo, Solid State Ionics, 86-88, 877 (1996).

14) S. Sotomura, S. Itoh, S. Kondo and T. Iwaki, Denki Kagaku, 59, 129 (1991).

15) T. Hara, N. Yasuda, M. Nagata, S. Kondo and T. Sotomura, Polymers for Advanced Technologies, 4, 194 (1992). 